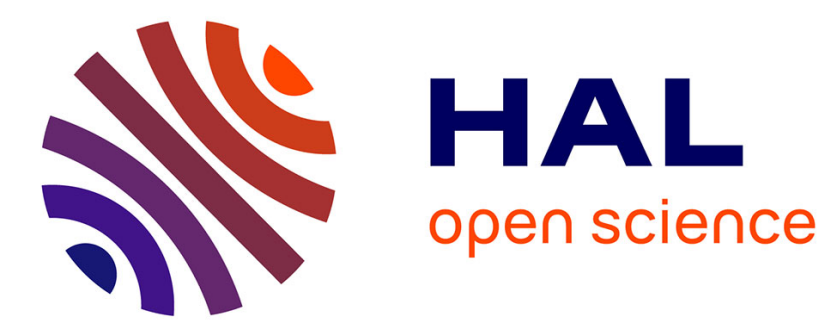

\title{
Phosphorus recycling potential assessment by a biological test applied to wastewater sludge
}

E. Braak, S. Auby, Simon Piveteau, Felipe Guilayn, M.L. Daumer

\section{To cite this version:}

E. Braak, S. Auby, Simon Piveteau, Felipe Guilayn, M.L. Daumer. Phosphorus recycling potential assessment by a biological test applied to wastewater sludge. Environmental Technology, 2016, 37 (11), pp.1398-1407. 10.1080/09593330.2015.1116612 . hal-02603392

\section{HAL Id: hal-02603392 \\ https://hal.inrae.fr/hal-02603392}

Submitted on 27 May 2020

HAL is a multi-disciplinary open access archive for the deposit and dissemination of scientific research documents, whether they are published or not. The documents may come from teaching and research institutions in France or abroad, or from public or private research centers.
L'archive ouverte pluridisciplinaire HAL, est destinée au dépôt et à la diffusion de documents scientifiques de niveau recherche, publiés ou non, émanant des établissements d'enseignement et de recherche français ou étrangers, des laboratoires publics ou privés. 


\section{Phosphorus recycling potential assessment by a biological test applied to wastewater sludge}

\section{Etienne Braak, Sarah Auby, Simon Piveteau, Felipe Guilayn \& Marie-Line Daumer}

To cite this article: Etienne Braak, Sarah Auby, Simon Piveteau, Felipe Guilayn \& Marie-Line Daumer (2016): Phosphorus recycling potential assessment by a biological test applied to wastewater sludge, Environmental Technology, DOI: 10.1080/09593330.2015.1116612

To link to this article: http://dx.doi.org/10.1080/09593330.2015.1116612

Published online: 19 Jan 2016.

Submit your article to this journal 지

Q

View related articles 주

View Crossmark data $₫$ 


\title{
Phosphorus recycling potential assessment by a biological test applied to wastewater sludge
}

\author{
Etienne Braak ${ }^{a}$, Sarah Auby ${ }^{a}$, Simon Piveteau ${ }^{a}$, Felipe Guilayn ${ }^{b}$ and Marie-Line Daumer ${ }^{a}$ \\ ${ }^{\mathrm{a}}$ Irstea,UR GERE, Rennes, France; ${ }^{\mathrm{b} U F S C}$ - Universidade Federal de Santa Catarina, Florianópolis, Brazil
}

\begin{abstract}
Phosphorus $(P)$ recycling as mineral fertilizer from wastewater activated sludge (WAS) depends on the amount that can be dissolved and separated from the organic matter before the final crystallization step. The aim of the biological phosphorus dissolution potential (BPDP) test developed here was to assess the maximum amount of $P$ that could be biologically released from WAS prior that the liquid phase enters the recovery process. It was first developed for sludge combining enhanced biological phosphorus removal and iron chloride. Because carbohydrates are known to induce acidification during the first stage of anaerobic digestion, sucrose was used as a co-substrate. Best results were obtained after 24-48 h, without inoculum, with a sugar/sludge ratio of $0.5 \mathrm{gCOD} / \mathrm{gVS}$ and under strict anaerobic conditions. Up to $75 \%$ of the total phosphorus in sludge from a wastewater treatment plant combining enhanced biological phosphorus removal and iron chloride phosphorus removal could be dissolved. Finally, the test was applied to assess BPDP from different sludge using alum compounds for $\mathrm{P}$ removal. No dissolution was observed when alum polychloride was used and less than $20 \%$ when alum sulphate was used. In all the cases, comparison to chemical acidification showed that the biological process was a major contributor to $\mathrm{P}$ dissolution. The possibility to crystallize struvite was discussed from the composition of the liquids obtained. The BPDP will be used not only to assess the potential for phosphorus recycling from sludge, but also to study the influence of the co-substrates available for anaerobic digestion of sludge.
\end{abstract}

ARTICLE HISTORY

Received 13 August 2015 Accepted 2 November 2015

\section{KEYWORDS}

Nutrient recovery; phosphorus; wastewater sludge; struvite; biological acidification

\section{Introduction}

Phosphorus $(P)$ is indispensable to human diet as it is a part of the energy carrier in cells (ADP/ATP), of DeoxyriboNucleic Acid (DNA), the main structures of genes, of bones and teeth and a lot of other tissues. It is not replaceable in plant cultivation and consequently for making food production sustainable, there is a need for sustainable access to the nutrient P.[1] As the $P$ life cycle does not include an atmospheric part, phosphorus cannot be considered as a renewable resource on short time scales. Coupled to the fact that $P$ extracted from mining activity represents the biggest part of fertilizer, there is a real need to set up $\mathrm{P}$ recovery and valorization processes, particularly regarding global food security. There is thus an increasing demand for nutrient recovery and $P$ from wastewater can be considered as a valuable resource. In wastewater treatment plants (WWTPs), P is typically present in effluent in concentrations around $10 \mathrm{mg} . \mathrm{L}^{-1}$ [2] although this value can suffer large variations. It has to be removed before water discharge in rivers. The limits vary from 0.2 to $2 \mathrm{mg} \cdot \mathrm{L}^{-1}$, depending on the local regulation. There are two ways developed to remove $\mathrm{P}$ from wastewater and concentrate it in sludge. The first one is by adding calcium, iron or alum to form solid minerals precipitated in sludge. The second one is known as enhanced biological $P$ removal (EBPR). It is based on phosphate accumulating organisms (PAO) able to accumulate more $P$ than strictly required for their metabolism. In anaerobic conditions the PAO are degrading the energy stored as polyphoshate and glycogen to stored short chain organic substrates like volatile fatty acids (VFA) as polyhydroxyalcanoates (PHA). Polyphosphate catabolism induces phosphate excretion in the media. In aerobic conditions or when electron receivers are available (anoxic stage), the PAO oxidize the PHA to regenerate the intracellular energy storage. $P$ accumulated during this phase is higher than the amount of $P$ released in the anaerobic one and so $\mathrm{P}$ is accumulated by the biomass.[3] Moreover, depending on the $\mathrm{pH}$ and on the calcium concentration in wastewater, a part of $\mathrm{P}$ released by the PAO can be precipitated with dissolved calcium or magnesium, contributing to $P$ accumulation in sludge. Depending on the legal limits for $P$ in the effluent, both EBPR and 
chemico-physical removal can co-exist. So more often, there are two main forms of $P$ in sludge. The first one is $P$ accumulated in PAO that can be released by anaerobic digestion (AD) when VFA are produced by acidogenic microorganisms from readily available carbon sources. The second one is calcium or iron phosphate salts that required low $\mathrm{pH}$ to be chemically dissolved. $\mathrm{P}$ in wastewater is rather diluted to make recovery and reuse feasible. Thereby, phosphorus-rich side streams or process water with phosphorus concentrations $>50 \mathrm{mg} / \mathrm{L}$ can be considered as economically rewarding.[4] So, usually, nutrient removal is performed after concentration in sludge, especially when WWTPs have anaerobic digestion, Indeed, the $P$ released at this stage is often recirculated directly back to the liquid processing stream with rather high concentrations. It can constitute about $20-30 \%$ of the load on the activated sludge system.[5,6] Crystallization reactor for struvite or calcium phosphate recovery can be implemented on these streams to recover $P$. Recovery of dissolved $P$ requires relatively basic technologies. This kind of system provides synergistic benefits to the plant as described in a recent paper that presents the first results from full-scale operation of a nutrient recovery facility in North America during three years.[7] The reduced nutrient loads in centrate $(85 \%$ less $P$ and $15 \%$ less ammonia) lowered the load to enhanced biological $P$ removal (EBPR) and made it more stable. This resulted in reducing alum, which induced a reduction in dry tons of sludge production. This sludge had less $P$, which could promote its beneficial reuse on farmland where $P$ concentration is limiting. The limiting step of $P$ recovery from wastewater is the solubilization of the $P$ concentrated in sludge. Cullen et al. [7] presented the first results obtained with a new process. The concept is to provide VFA to wastewater activated sludge (WAS) from EBPR in anaerobic conditions to increase $P$ release by PAO prior to anaerobic digestion. A simultaneous release of $\mathrm{Mg}$ occurs and the liquid stream is provided to a crystallization reactor. From laboratory- and pilotscale tests, phosphate release rates from the process were estimated to be between 25 and 40\%.[8-10] This configuration may have several beneficial impacts: higher amounts of soluble $\mathrm{P}$ and $\mathrm{Mg}$ in struvite recovery facility and decrease of these values in AD reactors which enables to prevent the formation of struvite on it and avoid the maintenance operation because of scaling. However, the minimum $\mathrm{pH}$ reached by this process was close to 6.5 , which is too high to dissolve a significant amount of mineral $P$ salts and to avoid precipitation, of a part of the P biologically released by the PAO with calcium or iron. Another solution to solubilize $\mathrm{P}$ is chemical acidification.[11] $\mathrm{P}$ is first solubilized in a tank with sulphuric acid dosage at $\mathrm{pH} 4$. Then metal ions are precipitated with citric acid. Finally, crystallization is carried out on the P-rich supernatant after $\mathrm{pH}$ adjustment (8.5 with $\mathrm{NaOH})$. In the first tests, a dissolution rate of $75 \%$ was obtained by these authors. In continuous operation at full scale during 5 months, the dissolution rate was 40 $80 \%$. Dissolution was the limiting process step and correlated directly to the phosphorus recovery rate since almost all of the dissolved phosphorus (approx. 98\%) precipitates, mostly as struvite. Comparable results were obtained by chemical acidification performed to dissolve $\mathrm{P}$ from pig manure in order to recover it as struvite at a pilot scale. Chemical acidification was also the limiting step from an economic point of view.[12] Most of the WWTPs are combining EBPR and iron or alum salts to reach the $P$ limit in the effluent.[13] The distribution of $\mathrm{P}$ between the intracellular forms (sensitive to biological release) and mineral forms (sensitive to chemical dissolution) depends on process configuration. Our midterm objective is to contribute to developing a process combining the biological and chemical mechanisms that enable maximal $\mathrm{P}$ solubilization during the hydrolysis stage. The aim is to provide selected substrate to PAOs in anaerobic conditions to enable the release of intracellular $P$ and lower the $\mathrm{pH}$, without the use of chemicals, to solubilize mineral forms of $\mathrm{P}$ and/or prevent crystallization of the released $P$ with magnesium or calcium. The following steps of the recovery process would be the same as those usually used on liquid effluent from digested sludge dewatering. Struvite crystallization process parameters and quality of the product will depend on characteristics of the liquid phase after biological $\mathrm{P}$ dissolution. [14] After being mixed with effluent from struvite crystallization ( $\mathrm{pH}$ about 8), sludge from the biological acidifying step could enter the anaerobic digestion process.

This paper presents the biological phosphorus dissolution potential (BPDP) test developed to compare, in standardized conditions, the maximum $P$ that could be released and remained dissolved by providing readily available carbon wastewater sludge depending on the previous $\mathrm{P}$ removal process parameters. The potential for struvite crystallization was discussed from the composition of the liquid phase obtained. It could also be used to compare the efficiency of different co-substrates in dissolving the $\mathrm{P}$ immobilized in a sludge.

\section{Materials and methods}

\section{Experiments}

Twenty-six biological tests and four chemical tests were performed. The conditions of the biological tests performed in this study are described in Table 1. 
Table 1. Biological dissolution tests. N2: inerted with N2.

\begin{tabular}{|c|c|c|c|c|c|}
\hline $\mathrm{N}^{\circ}$ & Objective & WAS & $\begin{array}{c}\mathrm{CoS} / \mathrm{S} \\
\mathrm{gCOD} / \mathrm{gVS}\end{array}$ & $\begin{array}{c}\text { B/I gVS/ } \\
\text { gVS }\end{array}$ & Air conditions \\
\hline B1 & Optimal coS/S ratio & S1a & 0 & - & Closed, $\mathrm{N}_{2}$ \\
\hline B2 & & S1a & 0.1 & - & \\
\hline B3 & & S1a & 0.5 & - & \\
\hline B4 & & S1a & 2 & - & \\
\hline B5 & & S1a & 5 & - & \\
\hline B6 & Influence of $\mathrm{O}_{2}$ & S1b & 0 & - & Closed, $\mathrm{N}_{2}$ \\
\hline B7 & & $\mathrm{s} 1 \mathrm{~b}$ & 0.5 & - & Closed, $\mathrm{N}_{2}$ \\
\hline B8 & & S1b & 0.5 & - & $\begin{array}{l}\mathrm{N}_{2} \text { after } \\
\text { opening }\end{array}$ \\
\hline B9 & & S1b & 0.5 & - & $\begin{array}{l}\text { No } \mathrm{N}_{2} \text { after } \\
\text { opening }\end{array}$ \\
\hline B10 & & $\mathrm{S} 1 \mathrm{~b}$ & 0.5 & - & Open \\
\hline B11 & $\begin{array}{l}\text { Influence of } \\
\text { inoculum }\end{array}$ & S1c & 0.5 & - & Closed, $\mathrm{N}_{2}$ \\
\hline B12 & & S1c & 0.5 & - & \\
\hline B13 & & S1c & 0.5 & 2 & \\
\hline B14 & & S1c & 0.5 & 5 & \\
\hline B15 & & S1C & 0.5 & 8 & \\
\hline B16 & & S1c & 0.5 & 11 & \\
\hline B17 & $\begin{array}{l}\text { Application to } \\
\text { other sludge }\end{array}$ & S2 & 0 & - & Closed, $\mathrm{N}_{2}$ \\
\hline B18 & & S2 & 0.5 & - & \\
\hline B19 & & S3 & 0 & - & \\
\hline B20 & & S3 & 0.5 & - & \\
\hline B21 & & 0 & 0.5 & - & \\
\hline B22 & & S2 & 0.5 & 2 & \\
\hline B23 & & S2 & 0.5 & 11 & \\
\hline B24 & & S3 & 0.5 & 2 & \\
\hline B25 & & S3 & 0.5 & 11 & \\
\hline B26 & Iron dissolution & S1d & 0.5 & - & Closed, N2 \\
\hline
\end{tabular}

\section{WAS samples}

Activated sludge was sampled on three different WWTPs with different phosphorus treatments: Measurements were realized on the same day of WAS sampling, except chemical acidification test of S1 (C1) which was performed after $24 \mathrm{~h}$ storage at $4^{\circ} \mathrm{C}$. Characteristics of the activated sludge are summed up in Table 2.

\section{Biological acidification tests}

Co-substrates ( $\operatorname{coS}$ ) with a high $\mathrm{C} / \mathrm{N}$ ratio are known to improve acidification.[15] To favour a short-term test, readily available carbon was provided as sucrose (commercial white sugar). To develop the test, thickened WAS (S1) coming from WWTP1 (with coupled EBPR and $P$ removal with $\mathrm{FeCl}_{3}$ ) was sampled just after centrifugation, the day of the tests, in the municipal WWTP close to the laboratory. It was diluted to around 25 gVSS. $\mathrm{kg}^{-1}$ to enable correct stirring. A volume of 640 $\mathrm{mL}$ of a mix of diluted WAS and sucrose (white sugar) was introduced in $1280 \mathrm{~mL}$ Erlenmeyer flasks which were closed with a rubber septum. Depending on the test, the gaseous top of the reactors was flushed with $\mathrm{N} 2$ to set anaerobic conditions before starting the process. Tests were run at $35^{\circ} \mathrm{C}$ with continuous stirring at $250 \mathrm{rpm}$ in batch mode. Overpressure was removed daily with a needle through the rubber septum to avoid vial burst. Liquid was sampled by a tap at the bottom of the Erlenmeyers which prevented the introduction of oxygen. Repeatability was assessed prior to the operation of these experiments by triplicates with sugar at loads of 2 and 5 gCOD.gVs ${ }^{-1}$ and provided more than $95 \%$ repeatability on $\mathrm{pH}$ and soluble P. Tests were consequently not duplicated.

\section{Inoculum preparation}

To study the influence of inoculum, an inoculum was prepared with sludge from WWTP1. In order to favour acidogenesis and to inhibit methanogenesis, the sludge was placed in a reactor under gentle mixing and fed with a solution of sucrose (ratio $0.5 \mathrm{gCOD} . \mathrm{gVS}^{-1}$ ). Because oxygen is not a problem for acidogenesis, the reactor was closed but not inerted with $\mathrm{N}_{2}$ at the beginning of the process. When the $\mathrm{pH}$ was stabilized at about 4 , the inoculum was used for experiments.

\section{Chemical acidification tests}

Chemical acidification tests were run on S1 (C1 and C4), S2 (C2) and S3 (C3) to estimate the fraction of P released by chemical mechanism. Perchloric acid $(0,5 \mathrm{~N})$ was used as acid. $\mathrm{pH}$ was maintained for $15 \mathrm{~min}$ at each $\mathrm{pH}$ value under continuous stirring and then lowered from 1 unit till reaching 2. Acidified activated sludge was sampled at every $\mathrm{pH}$ unit, and cation and anion concentrations were measured in the supernatant.

\section{Analysis}

Total solids (TS), volatile solids (VS), total Kjeldahl nitrogen (TKN) and chemical oxygen demand (COD) were measured with standard methods.[16] After an acidic mineralization $\left(110^{\circ} \mathrm{C}, 1 \mathrm{bar}, 60 \mathrm{~min}\right)$, Total phosphorus (TP) was analysed with ascorbic acid method using automated colorimetric methods on QuikChem ${ }^{\circledast} \mathrm{FIA}+$ from Lachat Instruments with QuikChem method 10-115-01-1-P. Supernatants were recovered after $20 \mathrm{~min}$ of centrifugation $\left(4^{\circ} \mathrm{C}, 20,000 \mathrm{~g}\right)$ and filtration on $0.45 \mu \mathrm{m}$ polypropylene membrane. lonic composition of the supernatant was measured with anion $\left(\mathrm{Cl}^{-}, \mathrm{NO}_{2}^{-}, \mathrm{NO}_{3}^{-}, \mathrm{PO}_{4}^{3-}, \mathrm{SO}_{4}^{2-}\right)$ and cation $\left(\mathrm{Na}^{+}, \mathrm{NH}_{4}^{+}, \mathrm{Mg}^{2+}, \mathrm{Ca}^{2+}, \mathrm{K}^{+}\right)$chromatography with Metrohm 940 Professional Vario IC, respectively, with Metrosep A sup 5 and Metrosep C4 -250/4,0 columns. Total calcium and magnesium were measured in the same conditions on mineralized products. Dissolved total iron was measured using Merck Spectroquant 1.14896.0001 kit and alum using Merck Spectroquant 1.00594.0001 kit. The analyses were run in triplicate. 


\section{Results and discussion}

\section{Determination of the Co-substrate/Sludge ratio}

The co-substrate/sludge ( $\cos / \mathrm{S})$ ratio was tested at 4 levels as described in Table 1 (tests B1-B5). The $\mathrm{pH}$ and ionic composition were measured on each sample at time 4, 24, 48, 72, 144 and $216 \mathrm{~h}$.

Low $\mathrm{pH}$ was reached at higher loads ( 2 and $5 \mathrm{gCOD}$. $\mathrm{gVS}^{-1}$ ) (Table 3). The $\mathrm{pH}$ quickly stabilized (between 24 and $48 \mathrm{~h}$ ) for the loads of $0.1,2$ and 5 gCOD.gVs ${ }^{-1}$, respectively, at around 5.7, 3.4 and 3.3. When the ratio was 0.5 , the $\mathrm{pH}$ quickly decreased to $4(24 \mathrm{~h})$ but increased up to 5.5 between $50 \mathrm{~h}$ and $150 \mathrm{~h}$ (Figure 1 (a)). For the higher loads, a first maximum of dissolved $\mathrm{P}$ was quickly reached ( $400 \mathrm{mg} . \mathrm{L}^{-1}$ at $24 \mathrm{~h}$ ), followed by a slight diminution which could be due to inhibition and a necessary re-adaptation on several days, and another maxima was observed around $540 \mathrm{mg}^{-\mathrm{L}^{-1}}$ at $144 \mathrm{~h}$. When the ratio was 0.5 , only one maximum $\left(520 \mathrm{mg.L}^{-1}\right.$ ) was reached after $50 \mathrm{~h}$ only (Figure $1(\mathrm{~b})$ ). Dealing with the test $\mathrm{B} 3$, soluble $\mathrm{P}$ seems strongly related to $\mathrm{pH}$ variations. Chemical precipitation of the biologically released $\mathrm{P}$ with calcium and magnesium could explain the $\mathrm{P}$ decrease when $\mathrm{pH}$ increased (Figure $1(\mathrm{c})$ and $1(\mathrm{~d})$ ).

The effect of the co-substrate load on $\mathrm{pH}$ and kinetics was in compliance with the literature even if in most of the studies the ratio is expressed in relation to the
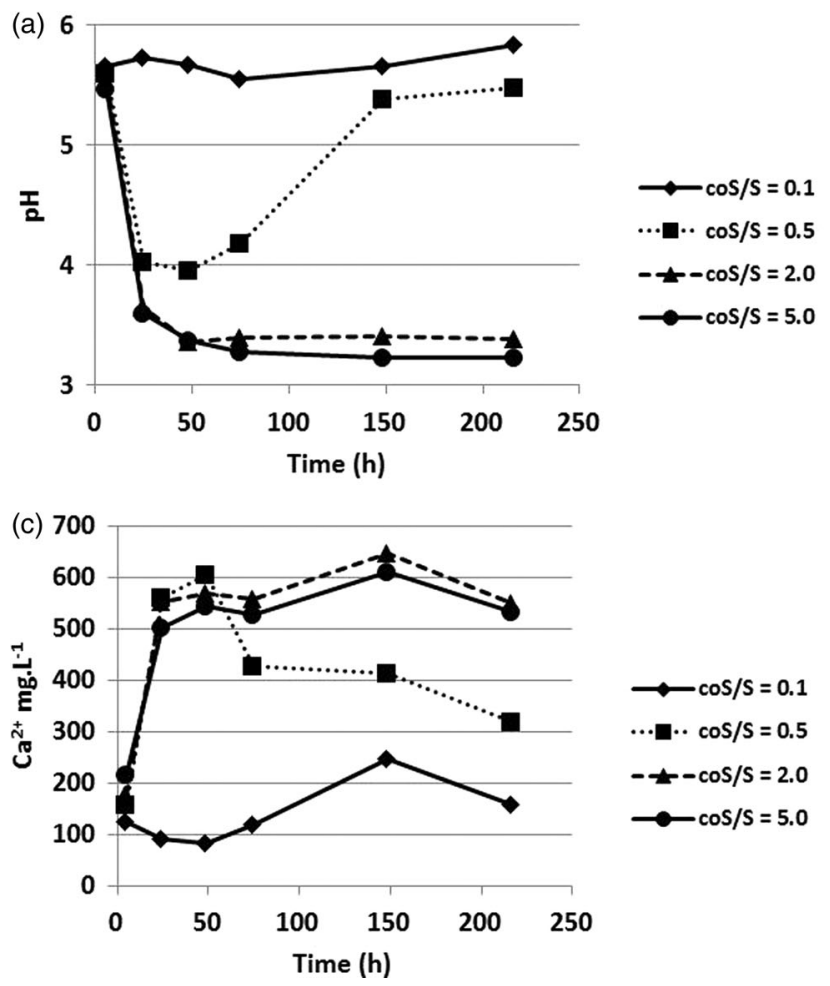

inoculum added.[17-19] Low $\mathrm{pH}$ is an inhibitor for methanogenesis that could explain why the VFA could accumulate, stabilizing the $\mathrm{pH}$ for the highest load. The inhibition of $\mathrm{P}$ released when $\mathrm{pH}$ is lower than 5 is also described by Wu et al. [20].

The following experiments were performed at 0.5 gCOD.gVS ${ }^{-1}$.

\section{Influence of oxygen}

To verify if it was possible to open the vial to add co-substrate or adjust $\mathrm{pH}$ during the test, five different tests were performed (B6-B10). From previous results the loading rate in the tests was chosen at $0.5 \mathrm{gCOD} / \mathrm{g}$. $\mathrm{VS}^{-1}$ and the duration was $48 \mathrm{~h}$. A control test in which the vial was closed without sugar was performed. Dissolved $\mathrm{O}_{2}$ was measured in all the reactors that have been opened at $6 \mathrm{~h}$. No dissolved oxygen was measured even in the continuously open flask.

The evolution of $\mathrm{pH}$ was the same in all the tests except the control. The $\mathrm{pH}$ reached 4 in $24 \mathrm{~h}$ and remained stable for $48 \mathrm{~h}$ (Figure 2(a)). On the contrary, the evolution of dissolved $\mathrm{P}$ was strongly dependent on the presence of air in the headspace.

When the flasks were closed and re-inerted just after 1 min opening, the evolution of dissolved $P$ was the same as in the permanently closed flask and reached the maximum ( $450 \mathrm{mg} \cdot \mathrm{L}^{-1}$ ) after $24 \mathrm{~h}$. If the flask was
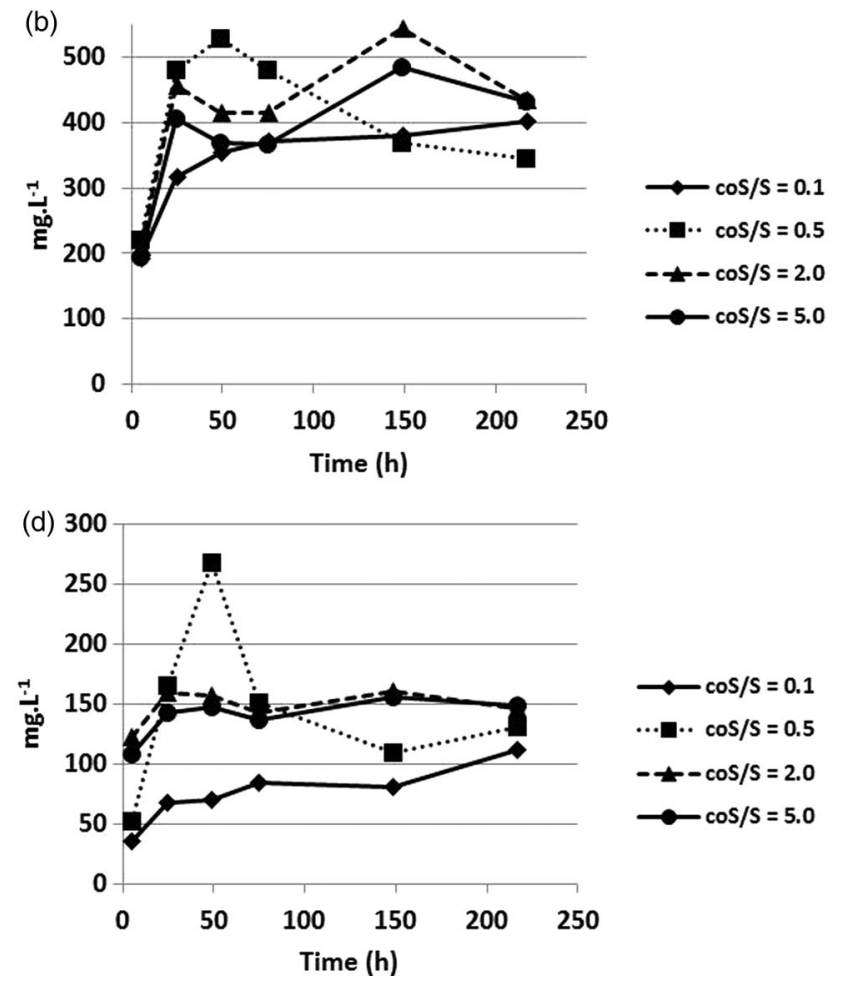

Figure 1. Evolution of $\mathrm{pH}(\mathrm{A})$, dissolved $\mathrm{P}(\mathrm{B}), \mathrm{Ca}^{2+}(\mathrm{C})$ and $\mathrm{Mg}^{2+}(\mathrm{D})$ depending on $\operatorname{coS} / \mathrm{S}$ ratio. 

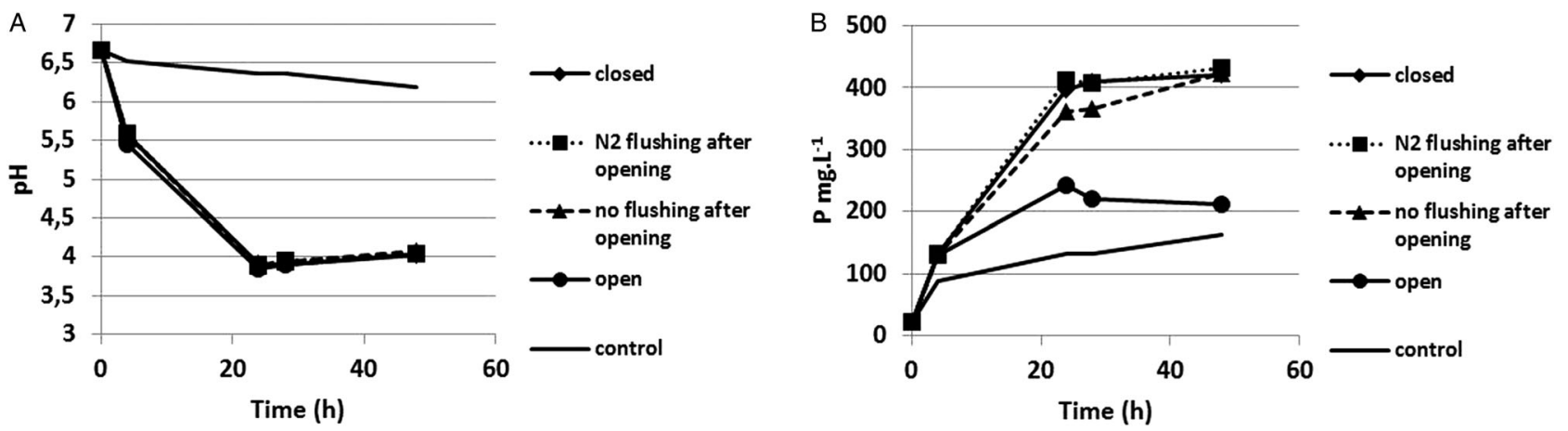

Figure 2. $\mathrm{pH}$ and dissolved $\mathrm{P}$ evolution depending on air in the headspace.

just closed without inerting, the maximum was obtained after $48 \mathrm{~h}$. In the open flask, even if no dissolved oxygen was measured, the dissolved $\mathrm{P}$ was only $250 \mathrm{mg} \cdot \mathrm{L}^{-1}$ at $24 \mathrm{~h}$ and remained stable for $48 \mathrm{~h}$ (Figure 2(b)). In this latter case, acidogenesis was not affected, but anoxic conditions were sufficient to inhibit $P$ release by the $\mathrm{PAO}$. These results are in compliance with the literature on EBPR which set up that when oxygen or another electron receiver is present, $\mathrm{PAO}$ oxidize the available carbon instead of storing it as PHA. So P is not released.[21,22]

The following experiments were performed under $\mathrm{N}_{2}$ atmosphere and the flasks were re-inerted when they had to be opened during the test.

\section{Influence of inoculum}

To see if it was possible to shorten the test with inoculum addition, 6 trials were performed at S/I ratio from 2 to 11 corresponding to $\operatorname{coS} / /$ ratio of $1,2.5,4$ and 5.5 , and two controls were run without inoculum (Table 1 tests B11B16).

Kinetics of both acidification and $\mathrm{P}$ dissolution were higher when an inoculum was added, but the ratio had no effect. The first inflexion of the dissolved $P$ curve occurred after $6 \mathrm{~h}$ when an inoculum was added. At this time, the dissolved $\mathrm{P}$ was $380 \mathrm{mg} \cdot \mathrm{L}^{-1}$ and $170 \mathrm{mg}$. $\mathrm{L}^{-1}$ with and without inoculum, respectively. However, after $6 \mathrm{~h}$ dissolved $\mathrm{P}$ increased quickly without inoculum when the dissolution was slowing down with inoculum. After $24 \mathrm{~h}$ dissolved $\mathrm{P}$ was maximal without inoculum (Figure 3). These results could be explained by the fast growth of acidogenic bacteria. After $24 \mathrm{~h}$, the activity of these endogeneous microorganisms would be even higher than those of the inoculum added. A high coS/l ratio is known to be responsible for methanogenesis inhibition due to acidification as described by Raposo et al. [18], Zhou et al. [19] or Hashimoto et al. [23].

The maximum was only $10 \%$ more $\left(550 \mathrm{mg}^{-1}\right)$ and reached later $(80 \mathrm{~h})$ with inoculum. Moreover, variability of the inoculum in time could contribute to variability in the test.

For sludge coming from the process including an EBPR stage, the BPDP test could be performed without inoculum.

\section{Chemical acidification}

To assess the role of the $\mathrm{pH}$ to the total $\mathrm{P}$ release during the biological test, acid was added to the sludge stored $24 \mathrm{~h}$, decreasing the pH step by step up to 2 . The curve could be described by a polynomial function described by Equation (1).

$$
\begin{aligned}
\mathrm{P}_{\mathrm{d}} & =7.1 \mathrm{pH}^{3}-92.7 \mathrm{pH}^{2}+311 \mathrm{pH}+35.7\left(R^{2}\right. \\
& =0.9851)
\end{aligned}
$$

This function was used to estimate the contribution of chemical dissolution due to low $\mathrm{pH}$ when dissolved $\mathrm{P}$ was maximum during biological tests B1-B5 (data at 24 and $48 \mathrm{~h}$ ).

The biological $\mathrm{P}$ release was calculated as the difference between total dissolved $P$ and chemically dissolved $\mathrm{P}$; non-dissolved $\mathrm{P}$ was the difference between total $\mathrm{P}$ and total dissolved $\mathrm{P}$. The contribution of chemical dissolution during the biological test increased, while $\mathrm{pH}$ decreased to reach $40-45 \%$ when the $\mathrm{pH}$ was under 4. Conversely, biological $\mathrm{P}$ release decreased when $\mathrm{pH}$ was under 4 probably due to PAO inhibition from the beginning of the test. Dissolved $\mathrm{P}$ was maximum at $\mathrm{pH} 4(77 \%)$ with an equal contribution of chemical and biological processes (Figure 4). When pH was above 4, the contribution of the biological process was probably underestimated because of precipitation of $P$ with cations.

Finally, in tests B1-B5, up to $77 \%$ of the total P from sludge resulting from combined EBPR and iron chloride $P$ removal process dissolved in a biological way at $48 \mathrm{~h}$. This high dissolution rate was the outcome of the combination of biological $P$ release by $\mathrm{PAO}$, due to easily 


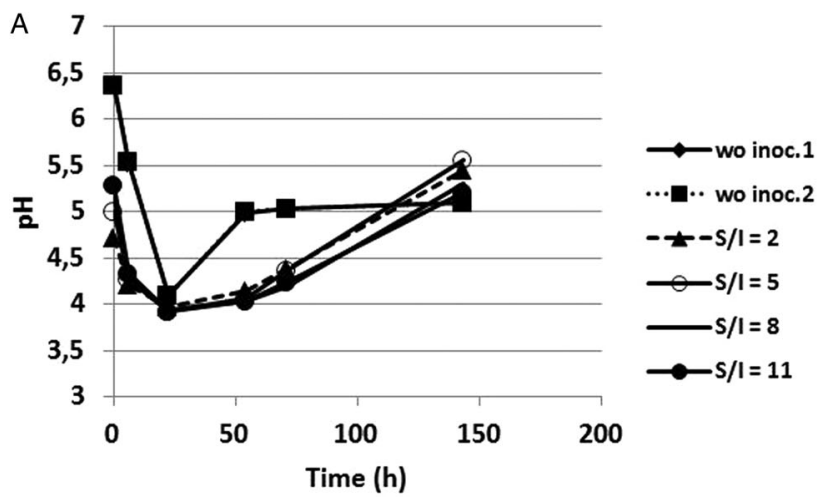

Figure 3. $\mathrm{pH}$ and dissolved $\mathrm{P}$ evolution depending on $\mathrm{S} / \mathrm{I}$ ratio.

biodegradable carbon provided in anaerobic conditions, and acidification induced by the co-substrate (sucrose), which maintained $P$ released in solution. The biological dissolution rate that we obtained was in compliance with Cullen et al. [7], who measured $25-40 \%$ of total P entering the crystallization process after that $P$ release had been favoured by VFA produced from primary sludge hydrolysis but at a $\mathrm{pH}$ close to 7 . Hydrolysis is usually studied as a way to increase methane production and very few references describe the influence of this stage on $\mathrm{P}$ dissolution. Depending on the $\mathrm{pH}, 250 \mathrm{mg}$. $\mathrm{L}^{-1}$ of dissolved $\mathrm{P}$ has been reached by Chen et al. [24] from WAS and $50 \mathrm{mg} \cdot \mathrm{L}^{-1}$ by $\mathrm{Wu}$ et al. [20] from primary sludge. However, no information on the wastewater treatment performed to produce WAS is available in the first paper and results are not discussed in regard of the total $P$ or cationic composition of sludge which are not presented in these studies.

The contribution of the chemical mechanism to biological dissolution that we observed $(30-75 \%$ when $\mathrm{pH}$ was below 4 in tests B1-B5) was corresponding to the value obtained by Antyakali et al. [11] by chemical acidification performed on digested sludge (40-80\%), but these authors were studying digested sludge where mineralization already occurred. The rate that we obtained by chemical acidification of S1a stored for $24 \mathrm{~h}$ (C1) (50\%) was higher than the results obtained on WAS by $\mathrm{Xu}$ et al. [25] (37\% at $\mathrm{pH} 2)$, but the value that we obtained with non-stored S1d (C4) (15\%) was lower. The amount of $P$ released from the biomass either by PAO metabolism during short-term anaerobic storage or by mineralization before chemical acidification seems to be the main driver of the amount that can be chemically dissolved.

\section{Evolution of iron during the BPDP test}

In order to discover what interferences could be caused by foreign cations during further struvite crystallization,

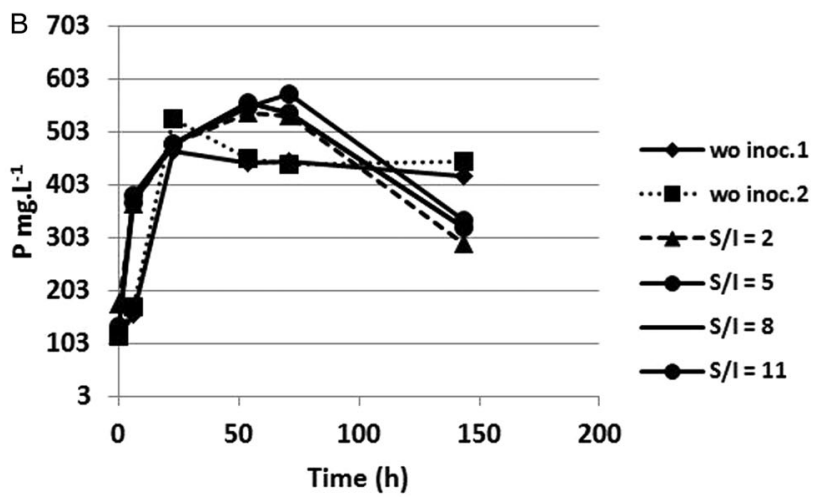

the iron concentration was measured during a new BPDP test (B26) performed on sludge from WWTP1 (S1d). For this experiment both biological and chemical acidification were performed on the sampling day. More than $82 \%$ of the total $\mathrm{P}$ was dissolved during this test. The contribution of the biological $P$ release to this result was $85 \%$. The contribution of the biological $\mathrm{P}$ released by the PAO was high compared to that of the biological test performed on sludge sampled in the same WWTP previously (B1-B5), and the contribution of acidification was low. Due to probable $\mathrm{P}$ released by PAO and precipitation during the $24 \mathrm{~h}$ storage at $4^{\circ} \mathrm{C}$, the effect of $\mathrm{pH}$ during the biological dissolution of sludge measured for B1-B5 could be overestimated.

Surprisingly, iron was dissolved as soon as the $\mathrm{P}$ was biologically released (Figure 5). To assess the contribution of $\mathrm{pH}$ to iron dissolution, Fe dissolution by chemical acidification was calculated from an acidification test performed on the same sludge as previously described for $\mathrm{P}(\mathrm{C} 6)$. Dissolved iron was related to the $\mathrm{pH}$ by a polynomial function described by Equation (2):

$$
\mathrm{Fe}_{d}=1.9 \mathrm{pH}^{2}-38.6 \mathrm{pH}+178\left(R^{2}=0.999\right)
$$

The amount of iron chemically dissolved during the biological test was estimated from this equation. It remained low compared to the biological dissolution and even when the $\mathrm{pH}$ was close to 4 , the contribution of chemical dissolution was less than $15 \%$. The biologically induced mechanism involved in Fe dissolution was not identified in this study.

Iron chloride dosing in WWTP is usually done considering that iron phosphate is the main compound responsible for $\mathrm{P}$ removal. Iron dissolution at relatively high $\mathrm{pH}$ showed that it was not the case in the sludge S1. PAO metabolism could induce some modification in the local chemical and physical conditions ( $\mathrm{pH}$, redox, etc.) or break down the organic matter structure, disrupting the complexes formed with iron, explaining $\mathrm{Fe}$ 


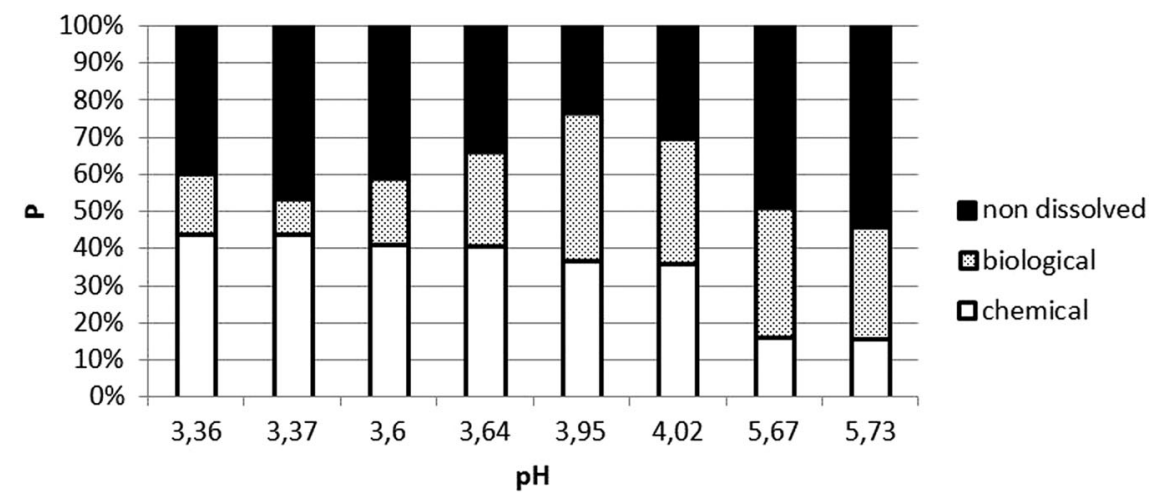

Figure 4. Contribution of chemical and biological processes to P dissolution during the BPDP test.

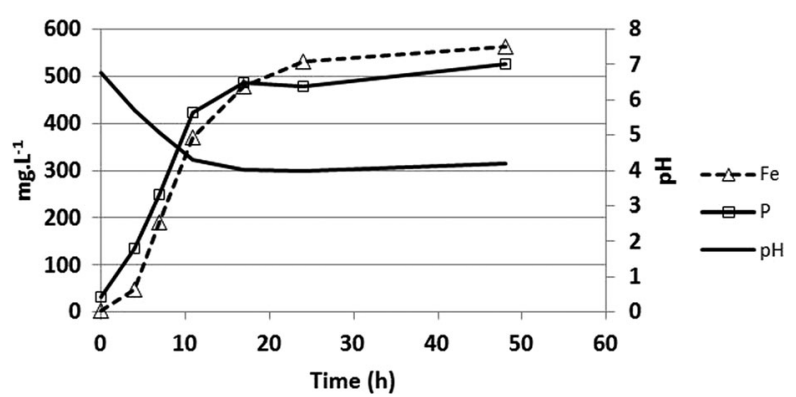

Figure 5. Fe and P dissolution during the BPDP test.

dissolution. The complexity of $\mathrm{P}$ and iron chemistry and relation to organic matter in sludge are worth studying in order to increase $P$ recycling potential as suggested by Wilfert et al. [13]. The influence of this high-dissolved iron concentration on struvite crystallization has to be taken into account too.

\section{Application to other sludge}

The BPDP test was applied to two different sludge coming from WWTP where $P$ was removed in a physico-chemical way (tests B17-B21). The first sludge S2 was coming from a WWTP which was supposed to use $\mathrm{FeCl}_{3}$ as the flocculent reagent. However, it was known afterwards that during the sampling period the sludge was mixed with sludge from drink water production using aluminium polychloride (sludge-PCAl) and no $\mathrm{FeCl}_{3}$ was added. For $\mathrm{S} 3$, the $\mathrm{P}$ removal was done with aluminium sulphate (Sludge-Al).

S2 was slightly acidified during the test (from pH 7.4 to 6.6) and $\mathrm{P}$ dissolution was not observed. Acidification was more efficient with S3 (from 6.6 to 4.1). However, P dissolution was limited to $18 \%$ of the total P. The difference between the sludge could be explained by biomass activity (no biomass able to degrade sugar in S2) or by the buffer effect of the sludge (Figure 6(a) and 6(b)).

As for S1, chemical acidification tests were performed on $\mathrm{S} 2$ and $\mathrm{S} 3(\mathrm{C} 2, \mathrm{C} 3)$, to estimate the contribution of the biological process to the dissolution. No dissolution was observed for $\mathrm{pH}$ above 5 for $\mathrm{S} 2$ and dissolved $\mathrm{P}$ was only $30 \mathrm{mg} \cdot \mathrm{L}^{-1}$ at $\mathrm{pH} 4$ for $\mathrm{S} 3$. The biological $\mathrm{P}$ release was contributing to $63 \%$ of $\mathrm{P}$ dissolved by the BPDP test in S3.

To test the possibility to improve acidification and $P$ dissolution by adding a biomass able to degrade sugar, an inoculum was prepared as described above and added at two levels $(S / I=2$ or $S / I=11)$ (tests B22-B25). $A$ control test was performed with the inoculum alone (B21). The $\mathrm{pH}$ was slightly lowered by inoculum and did not decrease under 5.5 whatever the ratio of $\mathrm{S} / \mathrm{l}$ tested for S2. No significant difference was observed at $24 \mathrm{~h}$ for S3, only the kinetic was changed (Figure 6(c) and 6(d)).

$P$ dissolution was not observed for S2. Moreover, the dissolved $\mathrm{P}$ brought by the inoculum was precipitated too. Two hypotheses could explain this. The biomass of the inoculum was inhibited by $\mathrm{S} 2$ and/or the $\mathrm{P}$ released from the inoculum was precipitated due to the high $\mathrm{pH}$ and the high Ca concentrations (Table 2). Contribution of the $P$ released from the inoculum was calculated from the dilution rate of the inoculum in sludge. The contribution of the P from S3 was calculated from the difference between the measured value and the calculated contribution of the inoculum. No increase in the $P$ released by the $S 3$ itself was observed. The higher dissolved $P$ was mainly due to the $P$ of the inoculum added. When the $B / I$ ratio was 2 , the dissolved $P$ was even less than the calculated contribution of $P$ from the inoculum (Figure 7).

The potential for $\mathrm{P}$ recycling from physico-chemical sludge using aluminium compounds was dependent on the flocculant. It remains low $(<20 \%)$ compared to the sludge from combined $\mathrm{EBPR}+\mathrm{FeCl}_{3}$ process (Table 3). As for Iron salts, alum and $P$ chemistry in sludge has to be investigated and the contribution of the biological process to Al dissolving has to be studied in order to explore the possibility to improve it. Unfortunately, sludge from WWTP using $\mathrm{FeCl}_{3}$ without EBPR could not be tested in this study. 

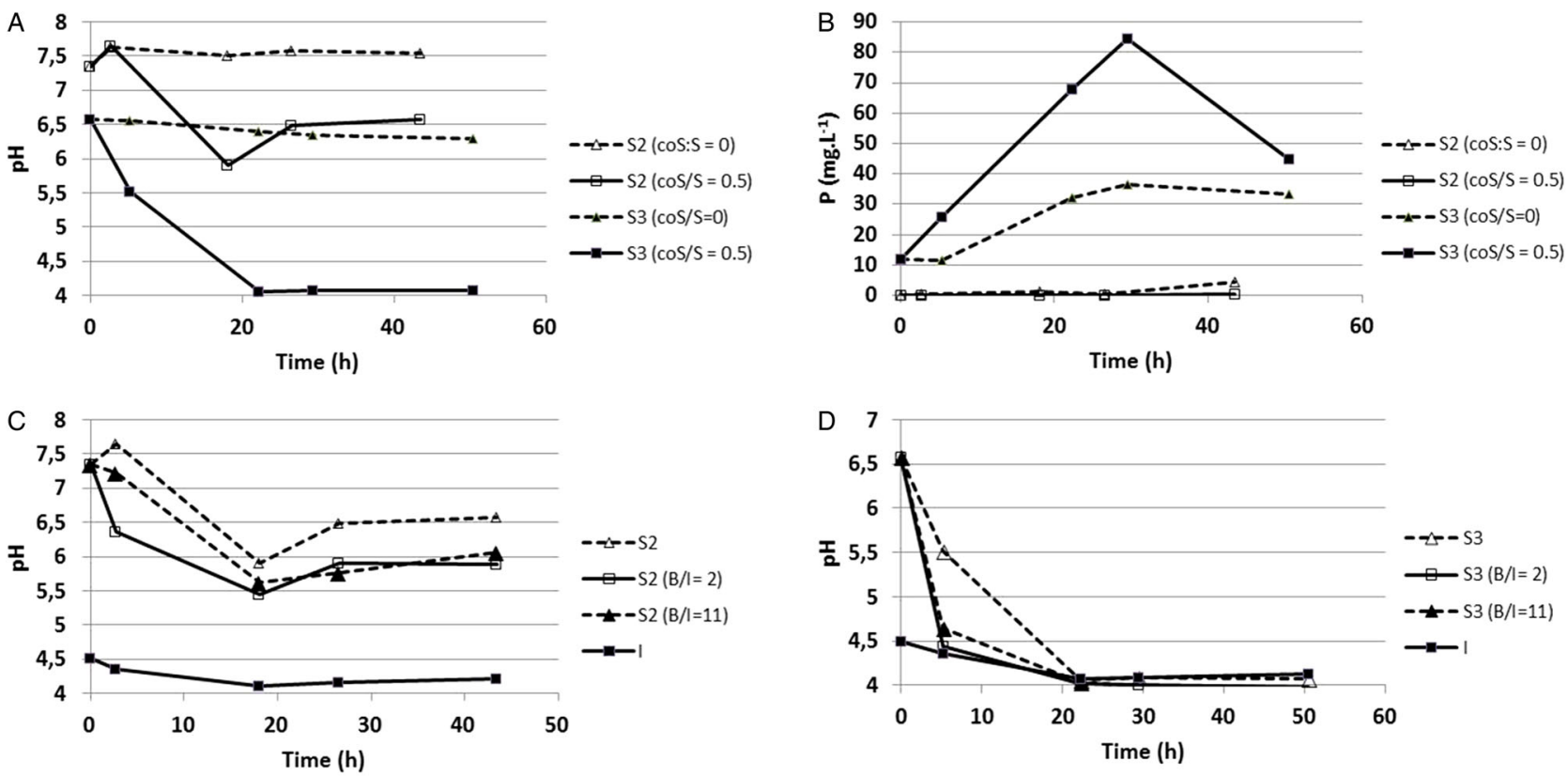

Figure 6. $\mathrm{pH}$ and dissolved $\mathrm{P}$ evolution during the BPDP test with and without inoculum. $\mathrm{A}$ and $\mathrm{B}$ : $\mathrm{pH}$ and dissolved $\mathrm{P}$ without inoculum. $\mathrm{C}$ and $\mathrm{D}: \mathrm{pH}$ with inoculum.

Table 2. Characteristics of WWTP sludge.

\begin{tabular}{|c|c|c|c|c|c|c|c|c|c|c|c|c|c|}
\hline \multirow{2}{*}{\multicolumn{2}{|c|}{$\mathrm{P}$ treatment }} & TS & VS & Total COD & Soluble COD & TKN & Soluble $\mathrm{NH}_{4}^{+}$ & Total P & $\mathrm{PO}_{4}^{3-}$ & Total Ca & $\mathrm{Ca}^{2+}$ soluble & Total Mg & $\mathrm{Mg}^{2+}$ soluble \\
\hline & & \multicolumn{2}{|c|}{$\overline{(g / k g)}$} & \multicolumn{10}{|c|}{$(\mathrm{mg} / \mathrm{L})$} \\
\hline S1a & $\mathrm{EBPR}+\mathrm{FeCl}_{3}$ & 48 & 35 & 51690 & 170 & 3070 & 17 & 1250 & 105 & 728 & 72 & 174 & 41 \\
\hline S1b & & 48 & 32 & nd & nd & nd & nd & 1115 & 22 & nd & nd & nd & nd \\
\hline S1C & & 44 & 30 & nd & nd & nd & nd & 1298 & 42 & nd & nd & nd & nd \\
\hline S1d & & 49 & 33 & nd & nd & nd & 2 & 1156 & 31 & nd & 44 & nd & 13 \\
\hline S2 & Sludge-PCAI & 32 & 19 & nd & nd & nd & 69 & 846 & 1 & nd & 231 & 133 & 59 \\
\hline S3 & Sludge-Al & 25 & 18 & 22060 & 120 & NA & 22 & 602 & 41 & 652 & 35 & 149 & 21 \\
\hline
\end{tabular}

\section{Potential for $\boldsymbol{P}$ recycling as struvite}

The ionic composition of the supernatant of biologically acidified sludge from WWTP1 (test B3) and WWTP3 (test B20) is presented in Table 4.

Struvite is an equimolar compound of $\mathrm{Mg}^{2+}, \mathrm{NH}_{4}^{+}$and $\mathrm{PO}_{4}{ }^{3-}$. Ammonium is the main limiting factor in the sludge $\mathrm{S} 1$ especially if we consider that when calcium is the main cation, the ratio should be more than one. to favour struvite instead of calcium phosphate precipitation [14] However, in the test, the co-substrate was only white sugar. At full scale, even if the most adapted co-substrate should be mainly carbohydrate, waste from the food industry very often contains nitrogen that could be degraded into ammoniacal nitrogen during the hydrolysis stage. If not, supernatant from digestate dewatering could be used as the nitrogen source for crystallization. Depending on the co-substrate composition, magnesium concentration should be adjusted too. The influence of ferrous or ferric ions on struvite crystallization is poorly documented. However, Antyakali et al. [11] consider that iron can be trapped by sodium citrate addition. The conditions for struvite crystallization are more favourable in the supernatant from WWTP3. N/P ratio is above 1 and the high Ca/ Mg ratio could be counterbalanced by adding magnesium in the reactor as it is usually done. Unfortunately, the sample from WWTP3 was spoiled before alum measurement in the supernatant. Nevertheless, the $\mathrm{P}$ dissolution rate by biological acidification was low and has to be improved to recycle significant amount of $P$ from this sludge.

The effect of dissolved organic matter as VFA on struvite crystallization is also poorly documented. A contradictory effect was demonstrated by Capdevielle [26] who showed that less struvite was formed but crystal size was increased by organic matter, aiming to better harvest the struvite crystals.

\section{Conclusions}

In the aim to replace chemical acidification by biological acidification before struvite crystallization in the $P$ recycling process from WAS, a BPDP test was designed. The best results were obtained after $24-48 \mathrm{~h}$, without 
Table 3. Minimum $\mathrm{pH}$, maximum dissolved $\mathrm{P}$ (\% of total $\mathrm{P}$ ) and relative contribution of the chemical and biological dissolution (\% dissolved P) in biological and chemical tests.

\begin{tabular}{|c|c|c|c|c|c|}
\hline $\mathrm{N}^{\circ}$ & Objective & $\mathrm{pHmin}$ & $\begin{array}{c}P_{d} \max \\
(h)\end{array}$ & $P_{d}$ bio & $P_{d}$ chem \\
\hline & & & \%Ptotal & \multicolumn{2}{|c|}{$\begin{array}{l}\text { Approximate } \\
\text { relative } \\
\text { contribution } \\
(\%)\end{array}$} \\
\hline B1 & Optimal coS/S ratio & & & & \\
\hline B2 & & 5.6 & $58(216)$ & 70 & 30 \\
\hline B3 & & 3.9 & $77(48)$ & 50 & 50 \\
\hline B4 & & 3.3 & 79 (144) & 40 & 60 \\
\hline B5 & & 3.2 & 71 (144) & 25 & 75 \\
\hline B6 & Influence of $\mathrm{O}_{2}$ & 6.2 & $27(48)$ & nd & nd \\
\hline B7 & & 3.9 & $69(48)$ & nd & nd \\
\hline B8 & & 3.9 & $70(48)$ & nd & nd \\
\hline B9 & & 3.9 & $69(48)$ & nd & nd \\
\hline B10 & & 3.9 & $40(48)$ & nd & nd \\
\hline B11 & Influence of Inoculum & 4.1 & $66(24)$ & nd & nd \\
\hline $\mathrm{B} 12$ & & 4.1 & $74(24)$ & nd & nd \\
\hline B13 & & 4.0 & $75(48)$ & nd & nd \\
\hline B14 & & 3.9 & $79(72)$ & nd & nd \\
\hline B15 & & 3.9 & $78(48)$ & nd & nd \\
\hline B16 & & 3.9 & $80(72)$ & nd & nd \\
\hline B17 & Application to other sludge & 7.4 & $<1$ & nd & nd \\
\hline B18 & & 5.9 & $<1$ & nd & nd \\
\hline B19 & & 6.3 & 10 & nd & nd \\
\hline B20 & & 4.1 & 14 & 65 & 35 \\
\hline B21 & & 4.1 & 63 & nd & nd \\
\hline $\mathrm{B} 22$ & & 5.4 & $<1$ & nd & nd \\
\hline B23 & & 5.6 & $<1$ & nd & nd \\
\hline B24 & & 4.0 & 28 & nd & nd \\
\hline B25 & & 4.0 & 20 & nd & nd \\
\hline $\mathrm{C} 1$ & Chemical dissolution by acid & 2.0 & 51 & - & 100 \\
\hline $\mathrm{C} 2$ & addition & 2.0 & nd & - & 100 \\
\hline $\mathrm{C} 3$ & & 2.0 & 30 & - & 100 \\
\hline B26 & Iron dissolution & 3.98 & $82(48)$ & 85 & 15 \\
\hline $\mathrm{C} 4$ & & 2 & 16 & - & 100 \\
\hline
\end{tabular}

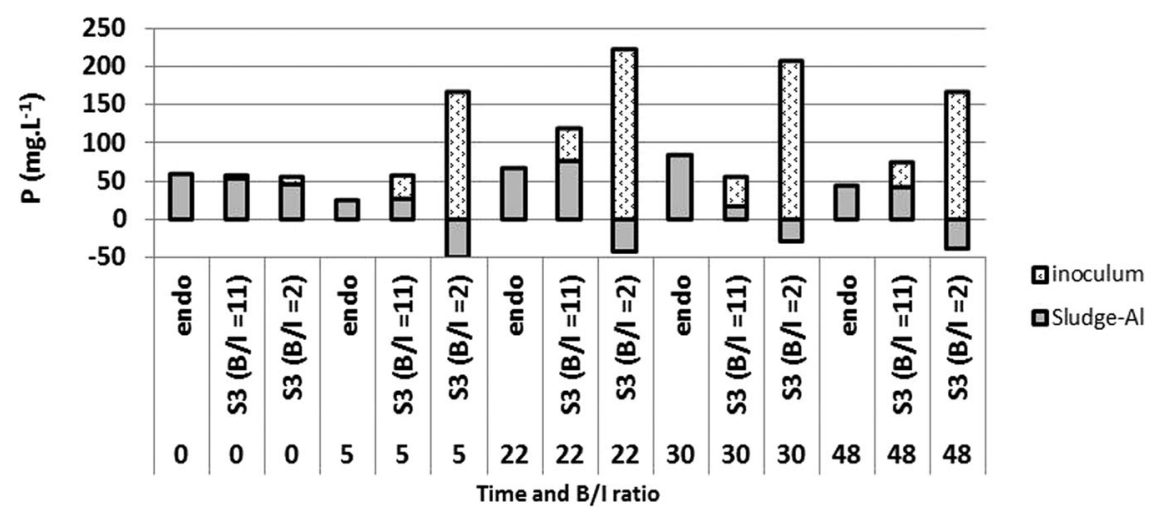

Figure 7. Contribution of the P from S3 and from the inoculum to the dissolved P measured during the BPDP test. Endo is sludge without inoculum.

inoculum, a sugar/sludge ratio of $0.5 \mathrm{gCOD} / \mathrm{gVSS}$ and under strict anaerobic conditions. Up to $82 \%$ of the initial total $P$ was dissolved by combining $P$ release and acidification at $\mathrm{pH}$ around 4 which maintained $\mathrm{P}$ in the sludge from WWTP by combining EBPR and iron chloride process for $P$ removal. No dissolution and a poor acidification were observed with sludge from WWTP using aluminium polychloride and less than $20 \%$ of the initial total
$P$ in sludge from WWTP using aluminium sulphate. The BPDP test will be used as a comparative tool to classify the sludge depending on their potential for biological $P$ dissolution and to establish a relation between $P$ dissolution potential and previous $P$ removal process parameters in the WWTP. It will enable assessing the acidifying potential of co-substrates and the potential for struvite formation depending on the liquid ionic 
Table 4. lonic concentrations $\left(\mathrm{mM}^{\mathrm{L}} \mathrm{L}^{-1}\right)$ in supernatant after the BPDP test (24 h).

\begin{tabular}{llccccc}
\hline & $\mathrm{P}$ treatment & $\mathrm{NH}_{4}^{+}$ & $\mathrm{PO}_{4}^{3-}$ & $\mathrm{Ca}^{2+}$ & $\mathrm{Mg}^{2+}$ & $\mathrm{Fe}^{2+}+\mathrm{Fe}^{3+}$ \\
\hline WWTP1 (S1a) & EBPR $+\mathrm{FeCl}_{3}$ & 3 & 16 & 14 & 7 & 10 \\
WWTP3 (S3) & Sludge-Al & 4 & 3 & 8 & 4 & - \\
\hline
\end{tabular}

composition. This study has also highlighted some mechanisms, poorly described in the literature because of the novelty of the concept of biological dissolution of $P$. These effects that have to be investigated with the aim of optimizing $P$ recovery rate from WAS, such as the role of biological metabolism on iron or alum dissolution and the influence of VFA on struvite crystallization.

\section{Disclosure statement}

No potential conflict of interest was reported by the authors.

\section{Funding}

This work was supported by the French National Agency for Water and Aquatic Environment (ONEMA) under Grant 'Action 49'-2013-2015.

\section{References}

[1] Linderholm K, Tillman AM, Mattsson JE. Life cycle assessment of phosphorus alternatives for Swedish agriculture. Resour Conserv Recycl. 2012;66:27-39.

[2] Yeoman S, Stephenson T, Lester JN, Perry R. The removal of Phosphorus during wastewater treatment: a review. Environ Pollut. 1988;49:183-233.

[3] Yuan, Z, Pratt S, Batstone DJ. Phosphorus recovery from wastewater through microbial processes. Curr Opin Biotechnol. 2012;23:878-883.

[4] Cornel P, Schaum C. Phosphorus recovery from wastewater: needs, technologies and costs. Water Sci Technol. 2009;59;1069-1076.

[5] Nyberg U, Aspergren $\mathrm{H}$, Andersson B, et al. Circulation of phosphorus in a system with biological P-removal and sludge digestion. Water Sci Tech. 1994;30:293.

[6] Wang Y, Zheng SJ, Pei LY, Peng DC, Xia SQ. Nutrient release, recovery and removal from waste sludge of a biological nutrient removal system. Environ Technol. 2014;35:2734-2742.

[7] Cullen N, Baur R, Schauer P. Three years of operation of North America's first nutrient recovery facility. Water Sci Technol. 2013;68:763-768.

[8] Schauer P, Baur R, Barnard J, Britton, A. Controlling Magnesium and Phosphorus to reduce Struvite precipitation in plant processes and increase revenue. Proc Water Environ Fed. 2009;4:926-947.

[9] Schauer P, Baur R, Barnard J, Britton A. Innovative phosphorus control to turn struvite headaches into increased revenue. Proc Water Environ Fed. 2009;14:3132-3150.

[10] Schauer P, Baur R, Barnard J, Britton A. Increasing revenue while reducing nuisance struvite precipitation: pilot scale testing of the WASSTRIP process. Proc Water Environ Fed. 2011;1:848-865.

[11] Antakyali D, Meyer C, Preyl V, Maier W, Steinmetz H. Largescale application of nutrient recovery from digested sludge as struvite. Water Pract Technol. 2013;8(2):256-262.

[12] Daumer ML, Picard S, Saint-Cast P, Dabert P. Technical and economical assessment of formic acid to recycle phosphorus from pig slurry by a combined acidification-precipitation process. J Hazard Mater. 2010;180:361-365.

[13] Wilfert P, Kumar PS, Korving L, Witkamp GJ, Van Loosdrecht $M$. The relevance of phosphorus and iron chemistry to the recovery of phosphorus from wastewater: a review. Environ Sci Technol. 2015:doi:10.1021/ acs.est.5b00150

[14] Capdevielle A, Sýkorová E, Béline F, Daumer ML. Kinetics of struvite precipitation in synthetic biologically treated swine wastewater. Environ Technol. 2014:doi:10.1080/ 09593330.2013 .865790

[15] Elbeshbishy E, Nakhla G. Batch anaerobic co-digestion of proteins and carbohydrates. Bioresour Technol. 2012;116:170-178.

[16] APHA. Standard methods for the examination of water and wastewater. 20th ed. Washington, DC: American Public Health Association; 1998.

[17] Tomei MC, Braguglia CM, Mininni G. Anaerobic degradation kinetics of particulate organic matter in untreated and sonicated sewage sludge: role of the inoculum. Bioresour Technol. 2008;99:6119-6126.

[18] Raposo F, Borja, R, Martín MA, Martín A, de la Rubia MA, Rincón $B$. Influence of inoculum-substrate ratio on the anaerobic digestion of sunflower oil cake in batch mode: process stability and kinetic evaluation. Chem Eng J. 2009;149:70-77.

[19] Zhou Y, Zhang Z, Nakamoto T, Li Y, Yang Y, Motoo U. Influence of substrate-to-inoculum ratio on the batch anaerobic digestion of bean curd refuse-okara under mesophilic conditions biomass and bioenergy. Biomass Bioenergy. 2011;35:3251-3256.

[20] $\mathrm{Wu}, \mathrm{H}$, Yang D, Zhou Q, Song Z. The effect of $\mathrm{pH}$ on anaerobic fermentation of primary sludge at room temperature. J Hazard Mater. 2009;172(1):196-201.

[21] Comeau Y, Oldham WK, Hall, KJ. Biochemical model for enhanced Biological Phosphorus removal. Water Res. 1986;20:1511-1521.

[22] Metcalf, E. Wastewater engineering (treatment and reuse). 4th ed. 1819p. New Delhi: McGraw-Hill; 2003.

[23] Hashimoto AG. Effect of inoculum/substrate ratio on methane yield and production rate from straw. Biol Wastes. 1989;28:247-255.

[24] Chen, Y, Jiang S, Yuan H, Zhou Q, Gu G. Hydrolysis and acidification of waste activated sludge at different pHs. Water Res. 2007;41:683-689.

[25] Xu Y, Hui H, Liu J, Luo J, Qian G, Wang A. pH dependent phosphorus release from waste activated sludge: contributions of phosphorus speciation. Chem Eng J. 2015;267:260-265.

[26] Capdevielle A, Sýkorová E, Béline F, Daumer ML. Effects of organic matter on the crystallization of struvite in biologically treated swine wastewater. Environ Technol. 2015;15: doi:10.1080/09593330.2015.1088580. 